УДК 378.013:81'243

DOI: $\underline{\text { https://doi.org/10.35619/iiu.v0i9.7 }}$

Ясногурська Людмила

кандидат філологічних наук, доцент кафедри іноземних мов

Рівненського державного гуманітарного університету, м. Рівне, Україна

ORCID: 0000-0003-3039-447X

e-mail: ludmillka21@ukr.net

\title{
ФОРМУВАННЯ МІЖКУЛЬТУРНОЇ КОМУНІКАТИВНОЇ КОМПЕТЕНЦІЇ СТУДЕНТІВ ПРИ ВИВЧЕННІ ІНОЗЕМНОЇ МОВИ
}

\begin{abstract}
Анотація. Статтю присвячено проблемі формування міжкультурної комунікативної компетенції студентів закладів вищої освіти. Розглядаються характеристики понять «компетентність», «компетенція», «міжкультурна комунікативна компетенція». Представлений процес формування цієї компетенції у студентів в умовах немовного вузу. У статті стверджується, що розуміння ролі іноземної мови, знайомство 3 культурою країни досліджуваного мови допомагає молоді усвідомити культурно-історичні цінності i сприяе формуванню міжкультурної комунікації. Полікультурне становлення сприяє гармонізації особистості молодої людини, взаєморозуміння і співпраці з представниками інших культур в студентському, а також і в професійному середовищі. Різноманітна палітра методів, прийомів подачі матеріалу ініціює моделювання соціокультурного простору, формує у студентів уявлення про навколишній світ. Виконуючи завдання, пов'язані з вивченням іншої культури, студенти асоціюють вивчений матеріал 3 реаліями української культури. Відбувається діалог культур, внаслідок чого формується міжкультурна комунікативна компетенція. Формування міжкультурної комунікативної компетенції слід розглядати в контексті з розвитком здатності студентів брати участь в діалозі культур на основі принципів взаємоповаги, терпимості до культурних відмінностей і подолання культурних бар'єрів.
\end{abstract}

Ключові слова: компетенція, міжкультурна комунікативна компетенція, компетентнісний підхід, міжкультурна комунікація.

Постановка проблеми. Процес глобалізації, що розвивається в наш час, призводить до розширення взаємодії різних країн, народів і їх культур. Досить довго побутувала думка про те, що непогане володіння іноземною мовою $\epsilon$ достатнім для успішного спілкування 3 представниками різних країн. Сьогодні ж такий підхід вважається застарілим. Одного вміння розмовляти іноземною мовою недостатньо для успішної комунікації. Людина також потребує великого запасу знань про культуру партнера зі спілкування. Раніше багато дослідників концентрувалися лише на формуванні вмінь у рамках комунікативної компетенції, проте зараз іноземну мову розглядають і як засіб засвоєння соціокультурного досвіду представників іншої лінгвокультурної спільноти. Як підтверджує практика навчання іноземної мови, інтерес до іншомовної культури пояснюється необхідністю успішного спілкування, яке $є$ неможливим без урахування культури в структурі і змісті комунікації як визначальної умови адаптації особистості до нових умов життя. Слід визнати, що досліджень в сфері формування професійних компетенцій у студентів за 
допомогою вивчення іноземної мови недостатньо. Пріоритетним завданням при навчанні англійської мови $є$ формування професійних компетенцій, спрямованих на практичне використання іноземної мови як інструменту реалізації професійних інтересів. У зв'язку з цим мають бути досліджені наступні завдання: звернути увагу на формування мовної та дискурсивної компетенцій; формувати іншомовний словниковий запас 3 професійної тематики; виготовити індивідуальні маршрути 3 оволодіння мовою, 3 метою пробудження мотивації до вивчення іноземної мови.

Аналіз останніх досліджень 3 проблеми. Проблема компетентнісного підходу отримала своє висвітлення в психолого-педагогічній літературі за такими напрямками: інноваційна модель професійної підготовки фахівців і компетентнісний підхід (Ю. Г. Татур, В. Д. Шадриков); компетенції як нова парадигма результатів освіти (І. О. Зимня); компетенції в сучасному суспільстві (Дж. Равен); професійна компетентність як якість освіти (А. А. Дорофєєв); сутнісні характеристики компетентності (О. Булавенко); технологія формування професійної компетентності (Л. Л. Нікітіна) (Раздобарова, 2008).

Мета статті - формування міжкультурної комунікативної компетенції студентів при вивченні іноземної мови разом із застосуванням компетентнісного підходу $є$ альтернативою однобічно-предметної орієнтації освіти.

Виклад основного матеріалу дослідження. Компетентнісний підхід передбачає не засвоєння студентом відокремлених один від одного знань і умінь, а оволодіння ними в комплексі (Фортова та Михалева, 2016). У реальному спілкуванні мовні засоби не є єдиним інструментом розуміння. Уявлення про культурну інформацію, правила i норми поведінки в іншомовному середовищі, вивчення ціннісних орієнтацій представників іншої культури $\epsilon$ не менш важливими. Звідси очевидною $\epsilon$ переорієнтація лінгводидактичних і методичних досліджень щодо проблеми міжкультурної комунікації, а точніше, на проблеми формування у студентів здатності ефективно брати участь в ній.

Розгляд компетентнісного підходу вимагає звернення до такого поняття, як компетенція. Компетенція розглядається як вимога до підготовки учня, виражене сукупністю взаємопов'язаних смислових орієнтацій, знань, умінь, навичок і досвіду діяльності учня щодо певного кола об'єктів реальної дійсності, необхідних для здійснення особистісної і соціально значущої продуктивної діяльності (Хуторской, 2003). Так, І. А. Зимова визначає міжкультурну комунікативну компетенцію як інтегральне особистісне утворення, що включає такі компоненти:

1) загальнокультурний (обізнаність в області загальних культурологічних знань і систем цінностей, що існують в різних країнах);

2) соціокультурний (володіння вміннями міжособистісного вербального спілкування $з$ представниками іншої країни, дотримання відповідних етичних та етикетних мовних норм);

3) лінгвосоціокультурний, що передбачає знання лексичних та граматичних одиниць, властивих мові різних країн, їх правильне використання в комунікативному процесі (Зимняя, 2003).

Формування міжкультурної комунікативної компетенції слід розглядати в контексті з розвитком здатності студентів брати участь в діалозі культур на 
основі принципів взаємоповаги, терпимості до культурних відмінностей i подолання культурних бар'єрів. Міжкультурне навчання спрямоване на формування у студентів здатності до міжкультурної комунікації і сприяє як усвідомленню студентами своєї приналежності до певного етносу, так i ознайомлення з традиціями і культурними особливостями представників іншої культури. У самому понятті міжкультурної комунікації закладено рівноправну взаємодію представників різних лінгвокультурних спільнот з урахуванням їхньої самобутності та своєрідності, що призводить до виявлення специфічності на основі порівняння іншомовної i власної культур. Міжкультурна комунікація як когнітивно-комунікативний простір відкриває нові можливості пізнання через розвиток когнітивної здібності учнів.

Вивчення іноземної культури починається 3 вивчення іноземної мови. Дізнаючись нову мовну форму, студент відкриває для себе ту частину культури, ту соціальну одиницю, яка знаходиться за нею, і це означає, що структура міжкультурної компетенції відображає характер освітньої компетенції і являє собою складне особистісне утворення, яке охоплює знання про рідну та іншу культуру, вміння і навички практичного застосування своїх знань, а також сукупність якостей особистості, що сприяють реалізації цих знань, умінь і навичок, i, зрештою, практичний досвід їх використання в процесі взаємодії 3 представниками іншої культури. Міжкультурна компетенція $€$ освітньою компетенцією при вивченні іноземної мови та іншомовної культури, при цьому об'єктом реальної дійсності при формуванні міжкультурної компетенції $\epsilon$ процес спілкування представників різних культур. Деякі вчені побоюються, що навчання міжкультурної комунікації може призвести до суперечностей 3 власною культурною ідентичністю: виникає побоювання втратити орієнтацію в звичному соціокультурному просторі, втратити ідентичність і втратити підтримку своєї групи, тому процес міжкультурного навчання повинен враховувати можливості виникнення такого роду протиріч.

У зв'язку з тим, що основним комунікативним партнером студентів $є$ викладач іноземної мови, слід також переглянути роль викладача в навчальному процесі. Викладачеві іноземної мови необхідно не тільки вміти на практиці використовувати іноземну мову як засіб спілкування, а й вміти моделювати різні комунікативні ситуації в навчальному процесі. Великий обсяг матеріалу, запропонований для вивчення, змушує шукати нові ефективні способи організації аудиторної, позааудиторної і самостійної роботи студентів, привносити в навчальний процес такі види і форми роботи, які розширюють пізнавальну активність, формують творчу особистість, здатну до комунікативної діяльності у вирішенні наукових, дослідницьких і практичних завдань. Потрібно вміти розробляти такі завдання, які б зацікавили студентів. Отже, однією з умов формування міжкультурної комунікативної компетенції $\epsilon$ готовність педагога ВНЗ до формування міжкультурної компетенції студентів: спрямованість педагога на формування міжкультурної компетентності студентів, розвиненість його професійного потенціалу, наявність інтересу до вивчення культури інших народів, знання сутності культури народів, носіїв мови, що вивчається; систематичне самовдосконалення у взаємозв'язку його теоретичної і практичної складових (Максимова, 2015).

При організації навчальних занять слід звернути увагу на таке: види мовної практики повинні бути пов'язані зі специфікою отримуваної 
спеціальності; мовленнєва взаємодія має відповідати поставленим цілям, а для цього необхідно організувати не тільки внутрішнє групове спілкування, а й цілеспрямоване виконання студентами самостійної роботи; центрування уваги на зміст висловлювання, а не на граматичних правилах.

На основі різноманітних методів i прийомів подачі матеріалу відбуваються моделювання соціокультурного простору, формування уявлень студентів про навколишній світ і визначення свого місця в ньому. Зміст окремих текстів, а також методичні прийоми роботи 3 ними допомагають студентам побачити себе в якості рівноправних представників світової спільноти, об'єднаних спільними інтересами (Раздобарова, 2008). Різноманітна палітра методів, прийомів подачі матеріалу ініціює моделювання соціокультурного простору, формує у студентів уявлення про навколишній світ. Виконуючи завдання, пов'язані з вивченням іншої культури, студенти асоціюють вивчений матеріал 3 реаліями української культури. Відбувається діалог культур, внаслідок чого формується міжкультурна комунікативна компетенція.

Висновки і перспективи подальших розвідок. Компетентнісний підхід виступає методом (технологією) моделювання результатів освіти як норм іiі якості. Він містить пріоритетну орієнтацію на особистісні та соціальні цілі і цінності освіти: здатність до навчання, самовизначення, спроможність до самореалізації та соціальної самовіддачі, колективної дії, співпраці. Ми вбачаємо у необхідності створення нового рівня стратегічної інтеграції, зокрема, й інструментального оснащення освіти, розробки поетапного переходу до нової моделі освіти, залучаючи застосування компетентнісного підходу при вивченні, зокрема, іноземної мови 3 одного боку, і рівня компетентності викладачів - 3 іншого.

\section{СПИСОК ВИКОРИСТАНИХ ДЖЕРЕЛ:}

Раздобарова, М. (2008). Межкультурная коммуникативная компетенция студентов в условиях модернизации профессионального образования. Известия Саратовского національного исследовательского государственного университета им. Н. Г. Чернышевского, №2, с. 121-123.

Фортова, Л. и Михалева, О. (2016). К вопросу о межкультурной коммуникативной компетенции студентов в современном профессиональном образовании. Молодой ученый, №12, с. 926-928.

Хуторской, А. (2003). Ключевые компетенции как компонент личностноориентированного образования. Народное образование, №2, с. 58-64.

Зимняя, И. (2003). Ключевые компетенции - новая парадигма результата образования. Педагогика, №3, с. 34-42.

Максимова, Э. (2015). Условия формирования межкультурной компетенции студентов неязыкового вуза в процессе обучения иностранным языкам. Социальноэкономические и технические системы: исследование, проектирование, оптимизация, №3, с. 129-138.

\section{REFERENCES:}

Razdobarova, M. (2008). Mezhkulturnaya kommunikativnaya kompetentsiya studentov $\mathrm{v}$ usloviyakh modernizatsii professionalnogo obrazovaniya. Izvestiya [Intercultural Communicative Competence of Students in the Modernization of Vocational Education]. Izviestiia Saratovskogo natsionalnogo issledovatelskogo gosudarstvennogo universiteta im. N. G. Chernyshevskogo, No2, s. 121-123. [in Russian] 
Fortova, L., Mikhaleva, O. (2016). K voprosu o mezhkulturnoy kommunikativnoy kompetentsii studentov $\mathrm{v}$ sovremennom professionalnom obrazovanii [To the Issue of Intercultural Communicative Competence of Students in Modern Vocational Education] Molodoy uchenyy, No12, s. 926-928. [in Russian]

Khutorskoy, A. (2003). Klyuchevyye kompetentsii kak komponent lichnostnooriyentirovannogo obrazovaniya [Key Competencies as a Component of Student-centered Education]. Narodnoye obrazovaniye, No 2, s. 58-64. [in Russian]

Zimnyaya. I. (2003). Klyuchevyye kompetentsii - novaya paradigma rezultata obrazovaniya [Key Competencies - a New Paradigm as the Result of Education]. Pedagogika, No 3, s. 34-42. [in Russian)

Maksimova, E. (2015). Usloviya formirovaniya mezhkulturnoy kompetentsii studentov neyazykovogo vuza v protsesse obucheniya inostrannym yazykam [Conditions for the Formation of the Intercultural Competence of Non-linguistic University Students in the Process of Learning Foreign Languages]. Sotsialno-ekonomicheskiye $i$ tekhnicheskiye sistemy: issledovaniye, proyektirovaniye, optimizatsiya, No 3, s. 129-138. [in Russian]

\title{
FORMING OF INTERCULTURAL COMMUNICATIVE COMPETENCY OF STUDENTS IN THE PROCESS OF FOREIGN LANGUAGE STUDY
}

\author{
Liudmyla Yasnohurska \\ Candidate of Philological Sciences, \\ Associate Professor at the Foreign Languages Department, \\ Rivne State University of the Humanities, \\ Rivne, Ukraine \\ ORCID: 0000-0003-3039-447X \\ e-mail:ludmillka21@ukr.net
}

\begin{abstract}
The article highlights the problem of forming students' intercultural communicative competence in higher educational establishments. The main essence of such concepts as expertise, competence and intercultural communicative competence is considered. The formation of the process of students' competence is described. The process of formation of such competence in a non-linguistic university is presented. The article emphasizes that understanding the role of a foreign language, familiarity with the culture of the country which language is studied helps young people to understand cultural and historical values and contributes to the formation of intercultural communication. Polycultural development contributes to the harmonization of a young person's personality, mutual understanding and cooperation with representatives of other cultures as well as broadening of students' professional environment. One of the conditions for the formation of intercultural communicative competence is the readiness of a university teacher to the formation of students' intercultural competence. The effective formation of the intercultural competence in the process of teaching foreign languages contributes to students' preparation for foreign language communication in cultural and professional areas. By performing tasks related to the study of different culture students associate the studied material with the realities of Ukrainian one. There is a dialogue of cultures resulting into intercultural communicative competence. Formation of intercultural communicative competence should be considered in the context of developing the ability of students to be engaged in a dialogue of cultures based on the principles of mutual respect, tolerance to cultural differences and overcoming cultural barriers. Intercultural communication deals with an equal interaction of representatives of various cultural communities taking into account their identity and peculiarities which lead to the identification of specificity on the basis of comparison of foreign languages
\end{abstract}


and their own cultures. Intercultural communication as a cognitive-communicative space opens new opportunities for cognition through the development of cognitive ability of students.

Key words: competence, intercultural communication competence, competencybased approach, intercultural communication.

Стаття надійшла до редакиії 21.03.2019 р. 